\title{
Ammoniation of straw by urea: extent of ureolysis and improvement of nutritive value with moderate water addition
}

\author{
JM Besle ${ }^{1}, M_{\text {Chenost }}{ }^{1}, \mathrm{JL}$ Tisserand ${ }^{2}$, JP Lemoine ${ }^{3}$, \\ F Faurie ${ }^{2}$, H Saleh ${ }^{2}$, N Grenet ${ }^{4}$ \\ 1 INRA-Unité de la Digestion Microbienne, Centre de Clermont-Fd/Theix, Theix, 63122 Ceyrat; \\ 2 INRA-ENSSAA, 26, bd Dr-Petitjean 21100 Dijon; ${ }^{3}$ Lycée Agricole, BP 42, 21801 Quetigny; \\ 4 ITEB-CRVZ, Theix 63122, Ceyrat, France
}

Introduction - Our purpose was to compare different urea treatments of straw, using an urease source or not, with a moderate addition of water.

Materials and Methods - In August, we added per $100 \mathrm{~kg}$ of wheat straw (85\% DM): 8 $\mathrm{kg}$ of urea (U), $8 \mathrm{~kg}+1.6 \mathrm{~kg}$ of enzyme active soybean flour (as urease source, Soyasol) (US), or $4.5 \mathrm{~kg}$ of ammonia (A). U, US and water (to reach a treated straw moisture of $30 \%$ ) were added by spraying on windrow (WU and WUS) or on cubic bales (BU and BUS) of $15 \mathrm{~kg}$. The stacks $(500 \mathrm{~kg})$ were covered with plastic sheets. After $17 \mathrm{wk}$, we determined nitrogen (N), urea, organic matter digestibility (OMD) (in vivo, feed restricted at $30 \mathrm{~g} / \mathrm{kg}$ Wo.75, or by densitometry for A, Besle ef al, 1989) and volontary intake (sheep).

Results and Discussion - Within urea (table I) treatments: 1) without soya, ureolysis was poor for BU, which had a correlatively low intake. The moderate result for WU was probably due to a good mixture with straw and to the long duration of the treatment; 2) with US, ureolysis was total for both techniques. When ureolysis was moderate: 1) $\mathrm{N}$ level was higher after urea than after $A$ treatment; 2) OMD improvement was the same for all ammonia sources; it was better when US was added to urea; 3) US improved intake.

In conclusion, urea treatment of straw can be achieved saving water, by spraying bales. Results were close to those obtained with $A$ provided a urease source was added.

Acknowledgments - Thanks to ITEB and to the Agricultural Ministry (DPE, DGER) for its grant. Soyasol from SIO, 62, rue 1Tourguenieff, 78380 Bougival.

Besle JM, Signoret $C$, Chenost $M$, Aufrère J, Jamot $J$ (1989) In: Evaluation of Straws in Ruminant Feeding (Chenost $\mathrm{M}$, Reiniger $\mathrm{P}$, eds) CEC, Elsevier, London, 134-143

Table I. Characteristics of untreated (UT) and treated (see text) straw.

\begin{tabular}{lccccccc}
\hline & \multicolumn{7}{c}{ Treatments } \\
\cline { 2 - 7 } & $U T$ & $W U$ & WUS & $B U$ & BUS & A \\
\hline & & & & & & \\
Ureolysis (\%) & - & $81.2^{\mathrm{a}}$ & $98.7^{\mathrm{b}}$ & $17.3^{\mathrm{c}}$ & $83.2^{\mathrm{a}}$ & - \\
Total N (g/kg DM) & $5.3^{\mathrm{a}}$ & $22.6^{\mathrm{b}}$ & $16.0^{\mathrm{c}}$ & $39.2^{\mathrm{d}}$ & $18.4^{\mathrm{c}}$ & $14.8^{\mathrm{a}}$ \\
OMD (\%) & $37.8^{\mathrm{a}}$ & $47.4^{\mathrm{b}}$ & $57.5^{\mathrm{c}}$ & $52.3^{\mathrm{d}}$ & $56.9^{\mathrm{c}}$ & $54.2^{\mathrm{c}}$ \\
intake (g/kg W0.75) & $34.6^{\mathrm{a}}$ & $32.1^{\mathrm{a}}$ & $47.7^{\mathrm{b}}$ & $29.7^{\mathrm{c}}$ & $65.2^{\mathrm{d}}$ & ND \\
\hline
\end{tabular}

